\title{
PERVERSE CONSEQUENCES OF WELL INTENTIONED REGULATION: EVIDENCE FROM INDIA'S CHILD LABOR BAN
}

\author{
Prashant Bharadwaj \\ Leah K. Lakdawala \\ Nicholas Li \\ Working Paper 19602 \\ http://www.nber.org/papers/w19602 \\ NATIONAL BUREAU OF ECONOMIC RESEARCH \\ 1050 Massachusetts Avenue \\ Cambridge, MA 02138 \\ October 2013
}

The views expressed herein are those of the authors and do not necessarily reflect the views of the National Bureau of Economic Research. Thanks to Chris Ahlin, Kate Antonovics, Jeff Clemens, Julie Cullen, Gordon Dahl, Rahul Deb, Eric Edmonds, James Fenske, Gordon Hanson, Anjini Kochar, Craig McIntosh, Arijit Mukherjee, Karthik Muralidharan, Paul Niehaus, Mallesh Pai and Maher Said for insightful discussions on the topic. Zachary Breig provided excellent research assistance.

NBER working papers are circulated for discussion and comment purposes. They have not been peerreviewed or been subject to the review by the NBER Board of Directors that accompanies official NBER publications.

(C) 2013 by Prashant Bharadwaj, Leah K. Lakdawala, and Nicholas Li. All rights reserved. Short sections of text, not to exceed two paragraphs, may be quoted without explicit permission provided that full credit, including $\odot$ notice, is given to the source. 
Perverse Consequences of Well Intentioned Regulation: Evidence from India's Child Labor $\square$ Ban Prashant Bharadwaj, Leah K. Lakdawala, and Nicholas Li

NBER Working Paper No. 19602

October 2013

JEL No. J08,O1

\begin{abstract}
While bans against child labor are a common policy tool, there is very little empirical evidence validating their effectiveness. In this paper, we examine the consequences of India's landmark legislation against child labor, the Child Labor (Prohibition and Regulation) Act of 1986. Using data from employment surveys conducted before and after the ban, and using age restrictions that determined who the ban applied to, we show that child wages decrease and child labor increases after the ban. These results are consistent with a theoretical model building on the seminal work of Basu and Van (1998) and Basu (2005), where families use child labor to reach subsistence constraints and where child wages decrease in response to bans, leading poor families to utilize more child labor. The increase in child labor comes at the expense of reduced school enrollment. We also examine the effects of the ban at the household level. Using linked consumption and expenditure data, we find that along various margins of household expenditure, consumption, calorie intake and asset holdings, households are worse off after the ban.
\end{abstract}

\author{
Prashant Bharadwaj \\ Nicholas Li \\ Department of Economics \\ University of California, San Diego \\ 9500 Gilman Drive \#0508 \\ La Jolla, CA 92093 \\ and NBER \\ prbharadwaj@ucsd.edu \\ University of Toronto \\ 150 St. George Street \\ \#334 Toronto, ON \\ Canada M5S 3G7 C \\ nick.li@utoronto.ca \\ Leah K. Lakdawala \\ Department of Economics \\ Michigan State University \\ 486 W. Circle Drive \\ 110 Marshall-Adams Hall \\ East Lansing, MI 48824 \\ lkl@msu.edu
}

An online appendix is available at:

http://www.nber.org/data-appendix/w19602 


\section{INTRODUCTION}

Legal interventions are a common tool used by societies seeking to bring about equality and justice. Bans against child marriage, racial segregation in schooling, and discriminatory hiring practices are prime examples of legal action intended to improve overall welfare and bring about equality of opportunity. While legal interventions have undoubtedly been effective in many situations, the possibility that well-intentioned laws can have perverse or self-defeating consequences is a central concern in the economic analysis of laws and regulations (Sunstein 1994). This possibility is crucial when evaluating the consequences of legal action taken against a controversial yet pervasive aspect of developing societies: child labor.

Despite facing near universal opposition for decades, child labor is endemic. According to a recent report by the International Labor Organization, there are nearly 168 million child laborers, of whom 85 million work under hazardous conditions (International Labour Organization (2013)). While many policy options exist to adress this, laws banning or regulating child labor remain the predominant response. ${ }^{1}$ However, the effect of these laws on child labor and household welfare is theoretically ambiguous (see Basu and Van (1998) and Baland and Robinson (2000)). The obvious mechanism is that when enforced, bans increase the cost to employers of hiring children thereby deterring their use. A less obvious mechanism, studied in detail by Basu (1999, 2005), pushes in the opposite direction: if only the poorest families use child labor in order to reach subsistence, a fall in child wages due to the ban may actually lead them to supply more child labor. Given the theoretical ambiguities in academic work, what does rigorous empirical work have to say about the impacts of such bans? In a comprehensive review, Edmonds (2007) concludes, “... despite all this policy discussion, there does not appear to be any study of the effectiveness of restrictions on work that would meet current standards of evidence.,"2 (pg. 66)

\footnotetext{
${ }^{1}$ Bans and regulations against child labor are common all over the world. In a detailed report published by the US Department of Labor's Bureau of International Labor Affairs, such regulations are found in countries like Egypt, Kenya, Nicaragua, Mexico and Thailand (US Department of Labor 1998).

${ }^{2}$ While there is a wealth of empirical and theoretical work examining the determinants (see excellent reviews by Basu (1999), Edmonds and Pavcnik (2005), Edmonds (2007)) and consequences (see for example Beegle, Dehejia and Gatti (2009)) of child labor there is little empirical evidence on the effectiveness of child labor bans. While there have been evaluations of policies like cash transfers that are directly intended to affect child labor (see Skoufias et al. (2001) among many others) and policies like trade liberalization that affect child labor indirectly through their overall labor markets impacts (see Edmonds and Pavcnik (2005b)), empirical evidence on the impacts of legislated child labor bans
} 
This paper sets out to fill this critical gap in the literature by examining the impact of India's flagship legislation against child labor, the Child Labor (Prohibition and Regulation) Act of 1986. Most recent articles in the press cite this law as the starting point for legal action against child labor in India. ${ }^{3}$ Our results are important for understanding the impacts of such bans in settings where people live at the margin of subsistence and where legal enforcement is weak. Given the dearth of rigorous evaluations of child labor bans in such settings, we offer several novel results.

First, we develop a simple model based on Basu (2005) to show that child labor bans can increase child labor in multiple sectors even if the ban only applies to one sector (as was the case with the 1986 ban). In Basu's one sector model, an imperfectly enforced ban lowers child wages, which forces families reliant on child labor income for subsistence to further increase levels of child labor. Our two sector extension of this model gives rise to three possible cases depending on the level of labor market frictions. The main insight is that as long as there are labor market frictions that prevent free movement of labor from one sector to another, a ban may increase child labor in both sectors. If there are no labor market frictions across sectors, a child labor ban in one sector results in a reallocation of child and adult labor between sectors but has no effect on overall levels of child labor.

Second, we test the predictions of the theory using nationally representative data from India. We estimate a difference in differences model using detailed data on employment from the 1983, 1987 and 1993 rounds of the National Sample Survey, which were integrated by IPUMS International.

We classify the 1983 round as the "pre-ban" period and the 1987 and 1993 rounds as the "post-ban" period. ${ }^{4}$ To account for other factors that may have affected wages and employment

is scarce. The set of papers most closely connected to ours are those that examine the historical role of child labor laws in reducing child labor in the United States. In an important article, Moehling (1999) finds that child labor laws barely contributed to the decline in child labor between 1890 and 1910, though Lleras-Muney (2002) shows that compulsory schooling and minimum working age laws did increase educational attainment between 1915 and 1935. Manacorda (2006) finds that own and siblings' employment status and schooling are affected by the legal working age eligibility in 1920 .

${ }^{3}$ A detailed description of the law is presented in Section 2 of this paper and in an online Appendix.

${ }^{4}$ As we discuss in section 2, it was not the case that before the 1986 law all forms of child labor were legal throughout India. However, this is not required by our empirical approach - the point is that the 1986 law tightened the rules on child labor overall and brought uniformity and awareness to the code. A related concern stems from recent work by Edmonds and Shrestha (2012). They document that minimum age regulations are rarely enforced across a broad set of developing countries by showing a lack of discontinuity in labor force participation around the minimum age. 
over time, we compare the changes in employment and wages of children below 14 to the changes of those above 14, before and after the law came into effect in 1986 since the Child Labor Act applied only to those under age 14. To tie the empirical work closely to the theoretical model, we also examine how the employment of children under 14 changes when their sibling is under or over the age of 14. The idea is that if adult labor supply is inelastic and the child labor ban only applies to children under the age of 14 , depressing their wages, the siblings of affected children are pushed into work. ${ }^{5}$

We find that child wages fall relative to adult wages after the ban; this relative decline occurs in the manufacturing sector targeted by the ban. We also find that a child below the age of 14 is more likely to work after the ban relative to someone just above the age of 14 . Using a more refined difference in difference approach dictated by the model, our results show that a child between the ages of 10-13 with a sibling below the age of 14 significantly increases his or her labor force participation by 0.8 percentage points compared to a child of the same age with a sibling over the age of 14 , which is approximately $5.6 \%$ over the pre-ban average participation for that age group. Similar to Boozer and Suri (2007) we find that the increase in child labor comes at the cost of human capital investments; a child affected by the ban is significantly less likely to be in school. A key aspect of the theory is that only the very poor supply child labor because in general households would prefer to not make their children work. Empirically, we use education of the household head and non-staple share of calories consumed as proxies for income and subsistence levels and find that most of the child labor increase comes from poorer families. ${ }^{6}$

Similarly, Boockmann (2010) finds little evidence that ILO minimum age conventions increase school attendance. Our findings are not inconsistent with these studies - we show that such laws can lead to more labor force participation and less schooling for those below the minimum legal working age, making the detection of such a discontinuity more difficult.

${ }^{5}$ While it would be interesting to examine responses along the intensive margin, the data do not contain any information on hours worked. While we use the term "siblings", the data only allow us to identify children in the same household. This strategy is similar to the one in Manacorda (2006), but differs in that we use siblings to define treatment status rather than explicitly measuring the impact of one sibling's labor supply on another. Hence, our estimation strategy is similar to what Manacorda calls the "reduced form" in his 2006 paper.

${ }^{6}$ Using data from the National Family Health Survey in India (1992 round) we find that education and asset holdings are highly correlated. Those with secondary school education score nearly a standard deviation more on an "asset index" compared to people without secondary school education. Non-staple share of calories is a welfare metric used in Jensen and Miller (2010). 
Third, we examine the consequences of the ban on various key components of household welfare. If an increase in child labor raises household consumption or wealth accumulation, then the overall welfare effects of the ban are harder to evaluate. We use linked expenditure and consumption surveys to show that household-level total expenditure, food expenditure, non-staple share of foods consumed and asset holdings decline significantly (although the magnitudes are small) after the ban. Combined with our findings for child labor and human capital, we take this as evidence that the ban makes these households, along various important components of household welfare, unambiguously worse off.

Our work highlights the importance of careful economic analysis of laws in a context where there could be multiple market failures (credit market failure is a prime example in this instance as noted in Baland and Robinson 2000). There exists a rich tradition of research at the intersection of law and economics in developed countries (Commons 1924, Stigler 1992); however, there is considerably less empirical work in developing countries. The effects of laws could be quite different in developing countries when they are not fully enforced due to weak institutions. The paper's analysis is broadly applicable to child labor bans in other developing countries where weak enforcement combined with a subsistence motive creates the potential for perverse effects. Hence, our paper speaks to the idea that optimal policy making in developing countries should take into account an environment of weak enforcement (as in the case of tax policy see Gordon and $\mathrm{Li}$ 2005) and non-standard behavior at the margin of subsistence (Jayachandran 2006).

Finally, our paper is related to the broader debate on rights-based activism in India (The Economist 2010). Current policy making in India involves legally guaranteeing certain "rights" such as the right to employment (NREGA) or the right to education. While such policies could have beneficial effects, understanding how such rights interact with the broader context of corruption and behavioral responses of poor households is crucial. Specific to our context, in February 2013 a bill was introduced to the Parliament of India calling for the abolition of all forms of child labor. Among other provisions, the proposed bill also calls for increased monitoring and punishment for violators of such laws. The results of this paper caution against such policies in the presence of broader institutional and market failures. 


\section{The Child Labor (Prohibition and Regulation) Act of 1986}

The impetus for the 1986 law $^{7}$ came from multiple reports from Government committees that suggested weak implementation of prior laws against child labor (see descriptions of these committee reports, the Sanat Mehta Committee of 1986, and the Gurupadaswamy Committee on Child Labor of 1979, in Ramanathan (2009); more details are provided in an online Appendix as well). The major innovation of the 1986 law was uniformity in the minimum age restriction people up to age 14 were defined as children and therefore ineligible to work in certain industries and occupations. Subsequent additions to the list of industries banned from hiring children under 14 were made at various points between 1989-2008.

The occupations subject to the ban after 1986 and before 1993 (the period we examine) were occupations that involved transport of passengers, catering establishments at railway stations, ports, foundries, handling of toxic or inflammable substances, handloom or power loom industry and mines among many others. The list of "processes" that were banned for children includes beedi (hand rolled cigarette) making, manufacturing of various kinds (matches, explosives, shellac, soap etc), construction, automobile repairs, production of garments etc. ${ }^{8}$ The major caveat to these bans was that agriculture was exempted and family-run businesses were allowed to hire their own children.

For the industries/processes where child labor was not explicitly banned, including agriculture, the 1986 law placed limits on how many hours and which hours children could work. For example, Section III of the law states that for every three hours of work, a child would get an hour of rest; no child shall work between $8 \mathrm{pm}$ and $7 \mathrm{am}$; and no child shall be permitted or required to work overtime. The only exception was child labor in household enterprises.

Importantly for our purpose, the law clearly states the penalties for employers who contravene the ban: "(1) Whoever employs any child or permits any child to work in contravention

\footnotetext{
${ }^{7}$ The entire Act of 1986 is available easily online and also from the authors.

${ }^{8}$ While these provisions came into effect immediately after the law was passed, a section of the law allowed for statespecific introduction of child labor regulation in sectors that were not explicitly banned. We focus on the impact of the centrally enacted law as using state level variation introduces additional selection concerns. If the state level component was the most critical component of the law then our current estimates based on the national minimum standards are likely biased downwards.
} 
of the provisions of section 3 [section detailing banned occupations] shall be punishable with imprisonment for a term which shall not be less than three months but which may extend to one year or with fine which shall not be less than ten thousand rupees but which may extend to twenty thousand rupees or with both. (2) Whoever, having been convicted of an offense under section 3, commits a like offense afterwards, he shall be punishable with imprisonment for a term which shall not be less than six months but which may extend to two years." Smaller fines are levied for failing to comply with the provisions that regulate the conditions under which children can work in approved occupations.

While enforcement of the 1986 law has been largely weak, it does appear that employers were aware of the law. According to a report by Human Rights Watch, many employers found loopholes to work around the specifics of the law. For example, the report (Human Rights Watch, 2003) provides anecdotal evidence on factories contracting with adults to take work home for their children since work at home was allowed under the terms of the law (see the online Appendix for details). Similar anecdotal evidence can be found in a Times of India article from 1994: "Employers neutralise the statutory ban on child labour by not showing them on the pay-roll. ... The local central excise staff of an inspection of home workers employed by a leading beedi company found that the output of a woman worker at Thatchanallur village was recorded in a passbook issued in the name of her husband. In the same village, Pitchammal and her daughter, Prema, had a passbook carrying the name of the Naina Moopanar, who had died years ago." ('Appalling plight of TN beedi workers', Times of India, August 6th, 1995; pg.7)

While hard data on prosecutions regarding child labor is difficult to come by, a Human Rights Watch report stated, "At the national level, from 1990 to 1993, 537 inspections were carried out under the Child Labour (Prohibition and Regulation) Act. These inspections turned up 1,203 violations. Inexplicably, only seven prosecutions were launched. At the state level, the years 1990 to 1993 produced 60,717 inspections in which 5,060 violations of the act were detected; 772 of these 5,060 violations resulted in convictions." (Human Rights Watch, 1996) While overall enforcement might have been weak, it seems that employers were more aware of the possibility of inspections and the consequent fines after the passage of the 1986 Act. In January 1987 a series 
of arrests in Ferozabad, Uttar Pradesh (an important center for bangle manufacturing) made the national news. This incident was heralded as the "beginning that has to be made somewhere in ending child labour" (Times of India, January 17, 1987; pg.18). Hence, we believe that the Act raised the level of inspections and awareness of the law as the government put renewed effort into enforcing the Act.

\section{MODEL}

In this section, we describe a basic model that illustrates the potential effects of a ban on child labor and several extensions. The model setup builds on the general equilibrium framework established in Basu (2005) and Basu and Van (1998). We begin with the simplest case in which there is one sector and describe the main predictions of the model when a ban on child labor is implemented, namely that a ban could lead to lower wages and increased levels of child labor. We then extend the intuition of this model to a setting with multiple sectors and with labor market frictions across sectors. We encourage the reader familiar with Basu (2005) and Basu and Van (1998) to skip directly to section 3.2. We use the same notation as in Basu (2005) and Basu and Van (1998) to preserve continuity with previous work.

\subsection{Effects of a child labor ban with one sector}

Consider a labor market in which there are two types of labor, adult and child. There is a representative firm with technology $Y=f(L)$ where $L$ represents effective units of labor. Child and adult labor are perfect substitutes in production up to a constant, $\gamma$; each unit of adult labor is equal to 1 unit of effective labor $\left(L^{A}=L\right)$ and each unit of child labor is worth $\gamma$ units of effective labor $\left(L^{C}=\gamma L\right)$, where $\gamma<1 .^{9}$ The price of output is normalized to 1 . Firms take prices as given; wages are $w^{A}$ and $w^{C}$ for adults and children, respectively. Now introduce an imperfectly enforced ban on child labor; firms found employing child labor are fined an amount $D$ and firms are audited with probability $p .^{10}$

\footnotetext{
${ }^{9}$ Existing empirical evidence suggests that employers treat child and adult labor as substitutes. See for example Doran (2013).

${ }^{10}$ (i) A more general specification of the ban allows the probability of detection to vary non-linearly with the level of child labor, i.e. where $p=p(L)$. Since firms are more likely to be detected the more children they hire, $p(L)$ is increasing in the amount of child labor employed. Here we assume a very simple linear form of $p(L)$, i.e. $p(L)=p L$,
} 
Since adult and child labor are perfect substitutes (after accounting for $\gamma$ ), firms are indifferent between hiring adults and children (as long as the marginal cost of labor is the same for both, i.e. when $\left.w^{C}=\gamma w^{A}-p D\right)$ and only care about satisfying total labor demand as implicitly defined by the first order condition $f^{\prime}\left(L^{*}\right)=w^{*}$ where $w$ represents the "total" marginal cost of labor (including any associated expected costs of the fine if the marginal unit of labor is child labor). ${ }^{11}$

There are $N$ families, each endowed with 1 (nondivisible) unit of adult labor which they supply inelastically and $m$ children who are also endowed with 1 unit of labor each. Households value their children's leisure (and/or schooling) and therefore supply child labor only in the case in which adult wages are not sufficient to reach subsistence consumption, $s$. When they do supply child labor, they do so only to the extent necessary to bridge the gap between subsistence consumption and income from adult work. ${ }^{12}$

We begin by limiting our attention to the case in which there is a single equilibrium, i.e. one in which total labor demand is sufficiently elastic such that the demand curve crosses the supply curve only once, where total labor demand exceeds the supply of adult labor and therefore at least some children are hired. ${ }^{13}$

where $p$ is a constant. When $p$ is large, a linear function may not be a suitable approximation for $p(L)$ as $p(L)$ may exceed 1 when both $p$ and $L$ are large. However, as discussed in the previous section, enforcement of the ban was perceived to be quite weak and thus $p$ was likely to be very low. In this case, a linear specification as an approximation of $p(L)$ is more justifiable, as there is less concern that $p(L)>1$.

(ii) Note that this definition of imperfect enforcement follows Basu (2005) and differs from Basu and Van (1998), which specifies that the ban is perfectly enforced for a proportion of firms while the remainder of firms are unregulated.

${ }^{11}$ To see the full firm maximization problem and the derivation of labor demand and supply curves as well as labor market equilibria, please see the Online Appendix.

${ }^{12}$ This framework is used to keep the analysis tractable but the behavior described in the model can be deduced from more general models of optimizing households; the results are based only on two essential assumptions: (1) child and adult labor are substitutes and (2) households prefer not to work their children if income is high enough. For example, see Basu and Van (1998) for a model in which children are less productive than adults but also consume less than adults, time is divisible so that children choose labor from a continuum of possibilities and household preferences are represented by a Stone-Geary utility function.

${ }^{13} \mathrm{As}$ in earlier work, this framework allows for multiple equilibria, where an economy can be in either a good equilibrium in which no children work (where $w^{A}<\frac{w^{C}+p D}{\gamma}$ and $N>L^{*}$ and aggregate firm demand is satisfied by aggregate adult labor supply) or a bad one in which children are forced to work (a possibility raised by Basu and Van (1998), Swinnerton and Rogers (1999), and Jafarey and Lahiri (2002)). When multiple equilibria exist and an economy is in the "bad" equilibrium, a perfectly enforced ban on child labor can jolt the economy to the "good" equilibrium, making households better off (see Basu and Van (1998) for details.) See the Online Appendix for the full definition of the equilibrium used in this model and for discussion of other equilibria. 
FIGURE 1. General equilibrium representation of the effect of an increase in fines on adult and child labor markets.

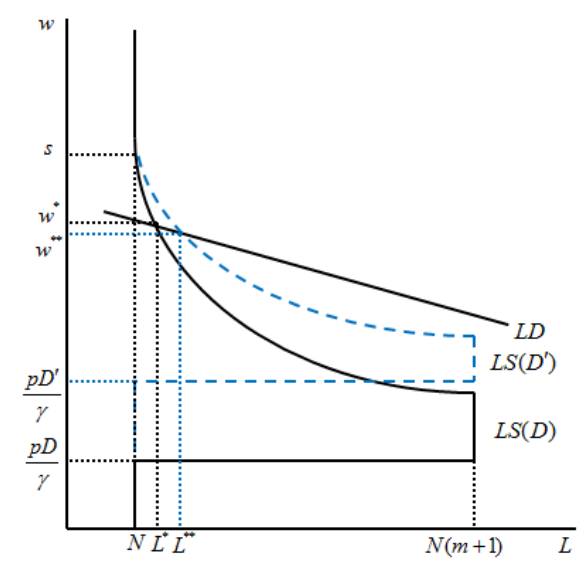

Figure reproduced from Basu (2005).

In this equilibrium, wages are equated in effective terms $w^{A *}=\frac{w^{C *}+p D}{\gamma}=w^{*}$ and we can represent general equilibrium in a single graph as in Figure 1. Here, the vertical axis represents the wage/marginal cost of an additional unit of labor (net of any expected fines), $w$, which is the same for both children and adults in effective terms. The horizontal axis represents aggregate effective units of labor (both adult and child).

Child labor supply within each household is given by

$$
S^{C}(w)=\left\{\begin{array}{cl}
0 & \text { if } w \geq s \text { or } \gamma w-p D \leq 0 \\
\min \left\{m, \frac{s-w}{\gamma w-p D}\right\} & \text { otherwise }
\end{array}\right.
$$

The intuition for the backward-bending labor supply curve is that for any given wage $w<s$, as the wage falls the household needs to supply more children to the labor market in order to reach subsistence consumption.

Consider the effects of increasing the fine levied on firms employing child labor from some initial level, $D$, to a new higher level $D^{\prime}$; for simplicity we can think of the case where $D=0$ (preban period) and $D^{\prime}>0$ (post-ban period). What is the effect of increased fines? Initially the increase in fines has no effect on total labor demand because child wages fall to offset the increase in fines, leaving the marginal cost of an effective unit of labor unchanged. This is because of the perfect substitutability between child and adult labor; since firms are indifferent between hiring 
adults and children, children must bear the full burden of the increase in expected fines. However the household supply curve shifts outward to $L S\left(D^{\prime}\right)$ as shown in Figure 1 because at every given $w$ children now earn less and household income is lower so more children must work to achieve subsistence. ${ }^{14}$ As more children flow into the market, this puts downward pressure on wages and the effective wage falls from $w^{*}$ to $w^{* *}$. Though both adult and child wages fall in response to the ban, child wages fall proportionally more than adult wages because they must also adjust for the higher costs associated with hiring child labor due to increased fines (the proof can be found in the Online Appendix). In the new general equilibrium $\left(w^{* *}, L^{* *}\right)$, total labor employed has increased and this increase has come only from children as households were already supplying all available adult labor before the ban.

\subsection{Two sectors, complete mobility}

Extending the baseline model to two sectors requires careful consideration of the underlying labor market conditions. In particular, the existence of labor market frictions that restrict the flow between sectors is very important for the implications of policies to restrict child labor. We assume that the labor supply and demand function in both sectors are as characterized above; namely that child labor supply is backward bending, the labor demand curve is elastic enough for there to exist a single equilibrium before the change in fines, and within each sector the labor markets for both adults and children must be in equilibrium with effective wages equalized. For the sake of brevity, we present the intuition of the two sector model here and leave the full discussion of the extension (including graphs) to the Online Appendix. In the following equations and figures, superscripts refer to person (Child, Adult) while subscripts refer to sector (manufacturing, agriculture). ${ }^{15}$

\footnotetext{
${ }^{14}$ In the Online Appendix, we outline how the shift in the child labor supply curve in the partial equilibrium analysis is due to the effect of the ban on household income through the channel of adult wages. General equilibrium labor supply responses of this nature are formally discussed in Basu et al. (1998).

${ }^{15}$ With the exception of the case in which there is no labor mobility, we assume that both manufacturing and agricultural jobs are available to at least some households. While one might expect that agricultural jobs are only available in rural areas and manufacturing jobs in urban areas, we find that children engage in both types of work regardless of location. Nearly $18 \%$ of working children (age 17 or less) in rural areas are engaged in "manufacturing" (defined in more detail in the next section), while $16.5 \%$ of working children in urban areas are employed in agricultural jobs.
} 
In the absence of any labor market frictions, the predictions of the Basu (2005) model break down. As long as labor is able to freely flow between sectors, wages equalize across sectors (even before the ban) so that $w_{a}^{*}=w_{m}^{*}=w^{*}$. Now consider a fine for employing child labor that is imposed in the manufacturing sector but not the agricultural sector. Children are now paid less in manufacturing, as their wages drop to offset the increased fine.

Since there is no ban imposed in the agricultural sector, all child labor flows from manufacturing into agriculture, where the child wages are unchanged. However, the influx of children into agriculture drives down all wages in that sector (though the opposite is true for manufacturing; the exit of children from manufacturing relieves pressure in that sector and thus increasing effective wages there). As a result, adult labor flows out of agriculture and into manufacturing (raising wages for those who stay in agriculture). Because labor moves freely, these labor flows continue until wages are once again equated between sectors. Aggregate effective demand for labor is unchanged; the cost of a marginal unit of effective labor has remained the same in each sector though firms reallocate the type of labor they use.

The end result of a ban in one sector when labor moves freely is a labor reallocation between sectors; the decrease in child labor in the manufacturing sector is exactly offset by the increase in child labor in the agricultural sector (in effective labor units). Only adult labor is employed in the sector where the fine has been levied as long as there is no shortage of adult labor supply. In that sector, adults continue to earn $w^{A *}$. Some mix of adult and child labor is employed in agriculture, earning $w^{A *}$ and $\gamma w^{A *}$, respectively. Because the shifts in adult labor exactly offset the opposite shifts in child labor caused by the fine, overall levels of child labor are unchanged although the composition of labor across sectors has changed. From a policymaking point of view, while the fine does not achieve its goal of reducing child labor, it does not lead to the perverse outcome of increased child labor as in Basu (2005).

\subsection{Two sectors, partial mobility}

Now consider a setting in which labor markets are imperfect such that there is limited mobility between sectors. ${ }^{16}$ In particular, while labor flows freely into agriculture, there are some

\footnotetext{
${ }^{16}$ See the Online Appendix for the discussion of the more extreme case when there is no mobility between sectors.
} 
barriers to entering manufacturing. For example, manufacturing jobs may require a different set of hard to acquire skills or may be limited to urban or semi-urban areas. One reasonable effect of such labor market frictions may be higher pre-ban wages in manufacturing relative to agriculture. Additionally, we assume that some children who have access to the agricultural market have household income coming from the manufacturing sector. ${ }^{17}$

In this partial mobility setting, an increased fine for hiring child labor in the manufacturing sector lowers wages in that sector. Unlike the full mobility case, labor cannot completely reallocate to "undo" the effects of the child labor ban; although children may flow out of manufacturing, adults will not be able to move from agriculture to manufacturing to replace the children who exit that sector. One of two possible cases can arise in response to the ban, depending on how much the fine lowers child manufacturing wages relative to child agricultural wages. In the first case, child wages are still higher in manufacturing than in agriculture, i.e. $\gamma w_{m}^{\prime}-p D^{\prime}>\gamma w_{a}^{\prime}$. Since children still earn more in manufacturing, those who hold manufacturing jobs are not induced to move to agriculture. However, due to the drop in child wages, the labor supply curve shifts out and adult wages fall in manufacturing. Since parental income drops for at least some households with children who have access to the agricultural labor market, child labor supply increases in the agricultural sector and wages decrease there as well. ${ }^{18}$ Thus after the ban, more children are working overall and all earn lower wages. Moreover, child wages fall proportionately more than adult wages in the manufacturing sector, while child and adult wages fall by the same proportion (and thus relative wages are unchanged) in the agricultural sector. ${ }^{19}$ This uneven drop in child wages in the manufacturing sector means that not only does overall child employment increase

\footnotetext{
${ }^{17}$ All of the qualitative results of the model go through as long as either there is at least partial labor mobility so that changes in the manufacturing market have effects on the agricultural market or some children who have access to the agricultural market have household income coming from the manufacturing sector. In the pre-ban data, we see that for individuals employed in agriculture, $23 \%$ live in a household where the head of the household works in "manufacturing" (defined in more detail in the next section). Therefore it seems likely that a sizeable portion of the agricultural sector will be affected by the wages being paid in the manufacturing even if there is no mobility between sectors.

${ }^{18}$ If children who have access to manufacturing jobs are affected by the lower wages in agriculture, this leads to an iterated increase in labor supply in both markets until the markets reach an equilibrium with increased effective labor and lower equilibrium wages in both sectors.

${ }^{19}$ The proof for this can be found in the Online Appendix.
} 
in response to the ban, but those families who have children working in manufacturing suffer the largest decreases in income and are most negatively affected by the ban.

In the second case, the ban lowers child wages in manufacturing by enough such that child wages in manufacturing fall below child wages in agriculture $\left(\gamma w_{m}^{\prime}<\gamma w_{a}^{\prime}\right){ }^{20}$ Intuitively, one could think of this as the case in which the government set $p$ and/or $D$ high enough to push children out of the manufacturing market. The large drop in child manufacturing wages leads children to exit manufacturing and enter agriculture. As they do so, adult wages rise in manufacturing generating an increase in household income. If this increase in income is enough reduce child labor supply by at least as much as the number of children who exit manufacturing, then the ban achieves its goal and wages rise in both sectors. However, if the manufacturing wage increase does not reduce the number of working children by at least the number of children who leave manufacturing, there will be more children working in agriculture post-ban and wages will be lower in that sector. The combination of the two effects - higher manufacturing wages but lower agricultural wages - leads to an ambiguous overall effect of the ban on levels of child labor relative to the pre-ban period.

\subsection{Summary of Theoretical Model}

In summary, the model illustrates that when we extend the canonical model to two sectors, child labor may rise and child wages may fall in response to an imperfectly enforced ban on child labor. The predictions of the model for individual sectors and for wage and employment responses vary depending on the state of the labor market. Perfect labor mobility allows for complete labor reallocation following a ban; while child labor falls to zero in manufacturing, compensating increases in child employment will be found in the agricultural sector leaving overall levels of child labor (and wages) unchanged. In contrast, when there is imperfect labor mobility, overall child labor could rise as a consequence of the ban, particularly when the ban is not well enforced. In this case, not only do all wages fall and aggregate child labor increases, but child wages fall relative to adult wages in manufacturing so that households whose children were working in manufacturing

\footnotetext{
${ }^{20}$ In reality there is a third case in which $\gamma w_{m}^{\prime}=\gamma w_{a}^{\prime}$. However, since the predictions for this case are very similar to
} the case where $\gamma w_{m}^{* \prime}>\gamma w_{a}^{\prime}$, the in-depth discussion of the third case is left for the Online Appendix. 
before the ban are particularly hard hit by the ill-effects of the ban. Even if a ban is very strictly enforced (high penalties and probability of inspection), it may still lead to higher overall levels of child labor if there is partial labor mobility and the ban is not successful enough in raising adult manufacturing wages.

\section{DATA}

\subsection{Employment and wage data}

The data we use to test the employment and wage predictions of this model are from the Integrated Public Use Microdata Series International (IPUMS) database for India. The database is built from the employment and unemployment surveys collected by the National Sample Survey Organization (NSS) of the Government of India. We make use of the 1983, 1987 and 1993 rounds of the survey as these most closely correspond to periods before and after the 1986 Child Labor Act.

We examine labor supply responses of nearly 515,000 children between the ages of 6 and 17 (roughly a third from each survey round). Tables $1 \mathrm{a}$ and $1 \mathrm{~b}$ give the summary statistics for this sample. Employment information is only collected for children over the age of 5 and therefore sample statistics are displayed only only for children 6 years and older. Child labor is generally decreasing over time; before the ban is in place, $14.8 \%$ of individuals age 6-17 are formally employed while after the ban the proportion falls to $11.7 \%$, although there is significant variation by age and gender.

Note that this measure of employment captures children who report working as their primary activity, in both paid and unpaid work and for employers, self-employment and family enterprises (including farms); the measure does not include children whose primary activity is domestic chores or housework as this is observed separately. We define "agricultural" employment as any employment in agriculture, fishing or forestry. We use the term "manufacturing" to refer to employment in any other industry (i.e. the converse of agricultural employment); these industries include (but are not limited to) mining, manufacturing, construction, wholesale and retail trade, 
and various services (e.g. in hotels, restaurants, and private households). Only about half of children are in school in 1983 but this proportion rises to nearly $65 \%$ in the later rounds of data. The children come from over 208,000 families, where the average family size is falling over time and education and non-agricultural employment is rising.

One concern with the data is the scope for measurement error in employment status, particularly with strategic underreporting of child labor. While we believe this measurement error does not present a serious problem for our estimating strategy described in the next section, we discuss this issue in great detail in Section 6, where we also address other potential threats to validity.

\subsection{Asset, consumption and nutrition data}

We calculate monthly per capita expenditures using Schedule 1.0 of the National Sample Survey (NSS) of India, which is linked to the Employment survey (Schedule 10.0) for the 38th, 43rd and 50th NSS rounds. The survey is based on a 30-day recall of household consumption for a detailed list of items. The survey records both quantities and expenditures, and also covers home produced goods (which have expenditures imputed at the farm-gate price). Our per capita expenditure measure excludes rent and taxes but includes all food, alcohol and tobacco, energy, clothing and footwear, service, non-durable and durable expenditure. We use the official price index for industrial workers to deflate expenditures across years so expenditure is measured in 1982 rupees.

We calculate monthly per capita food expenditures using only the food items from the survey and exclude alcohol. To deflate food prices we use a price index calculated directly from the survey - we use the median unit value by sector (rural/urban) and survey round to construct a Tornqvist price index with the Rural 50th round as the base.

To construct caloric intake at the household level we convert the recorded quantities into caloric intake using the standard caloric conversion factors that have been used for this purpose in the past (Gopalan et al. (1980)). ${ }^{21}$ Our calorie calculations include calories from alcohol. We

\footnotetext{
${ }^{21}$ We supplement this with data from other sources in a few cases. For some food items quantities and/or caloric conversion factors are not available so we use the imputation procedure described in detail in the appendix of Li and Eli (2013). We use the "liberal" conversion factor and impute using all food factors rather than the group factors.
} 
calculate a "staple share of calories" measure as the ratio of calories from cereals and cereal substitutes to calories from all sources (including alcohol). In our regression analysis we define " 1 staple share of calories" as a positive indicator of welfare for reasons we discuss later.

We also construct a household wealth/asset index using data on housing and some proxies for durable ownership. Although the 43rd and 50th NSS consumption modules record ownership of many different household durables, these data are missing for the 38th round so we are forced to rely on proxies such as the source of energy for lighting and cooking and household electricity ownership. To calculate the asset index, we calculate the principal component of the following set of discrete variables - source of cooking energy, source of lighting energy, floor type, wall/building type, house condition - and the continuous variables covered area and quantity of electricity used.

Our sample size varies slightly across our household-level specifications as some of our welfare measures are undefined (e.g. recorded expenditures or calories are zero, asset information is missing) or we were unable to link the employment and consumption surveys. All of the welfare measures increase on average between the pre and post ban period with the exception of calories per capita which decreases slightly (Table 2). As seen in Table 1 of the Online Appendix the pre-ban cross-sectional correlation between the welfare measures ranges from very high (0.92 correlation of per capita expenditures and per capita food expenditures) to moderate ( 0.44 to 0.57 correlation of per capita expenditures and the calorie, staple share and asset index measures).

\section{EMPIRICAL STRATEGY AND RESUlts}

\subsection{Effect of the ban on wages}

The model in the previous section indicates that one effect of the the ban on child labor is to reduce child wages relative to adult wages. To test this implication empirically, we use data on child wages to run the following difference-in-difference specification:

$$
\begin{aligned}
\log (\text { wage })_{i t}= & \gamma_{0}+\gamma_{1} \text { Under } 14_{i}+\gamma_{2}{\text { Post } 1986_{t}} \\
& +\gamma_{3}\left(\text { Under } 14_{i} \times \text { Post } 1986_{t}\right)+\gamma_{X} X_{i t}+\delta_{t}+\nu_{i t}
\end{aligned}
$$


$X_{i t}$ is a vector of household- and child-level covariates such as family size, household head characteristics, gender, and state-region fixed effects while $\delta_{t}$ captures survey year fixed effects.

According to the theory, wages for children (legally defined as those under 14) should fall relative to adult wages after the ban, i.e. $\gamma_{3}<0$. The identifying assumption in (2) is that in the absence of the ban, the difference in wages for those just above age 14 and those just below age 14 should be stable over time; the pre-ban to post-ban shift in relative wages for those just under 14 relative to those just over 14, controlling for other observable characteristics and year fixed effects, is then attributed to the ban.

In the data, wages are only reported for those engaged in regular or casual labor. Notably, this excludes children working in home enterprises and farms. Other groups that have wages recorded as zero include the unemployed, those working but unpaid, the self-employed, and beggars and prostitutes. Therefore the wage regressions are subject to the usual caveat - particularly important in developing countries - that they only apply to a select subsample of workers. ${ }^{22}$ Whether this leads to an under or overestimate of the drop in wages depends on the shadow wages of children pushed into or out of home production as a result of the ban. If shadow wages are equal to market wages our estimates will be unaffected. If shadow wages are below market wages (which is the likely case in this context), we will underestimate the fall in child wages due to the ban as our sample will leave out the lowest earners. While it is important to recognize the limitations of the wage data, our results will still be informative about the wages of those engaged in work outside the household, which is the focus of the theoretical model in Section 3. Our results on household expenditures also suggest that the pattern we find for market wages is at least partly reflected in household income, which includes proceeds from household farms and enterprises.

The results of estimating equation (2) on various samples are displayed in Table 3. The difference in difference coefficient in Table 2 shows consistent drops in child wages relative to adult wages and this effect is largely concentrated in the manufacturing industries (column 3). Consistent with the model from the previous section, we find no relative decrease in wages for children in agriculture. For narrower age ranges around 14, the wage effect is smaller than for

\footnotetext{
${ }^{22}$ Note that this does not affect our employment regressions, since we observe children's employment regardless of whether the work takes place within or outside the home.
} 
broader age ranges. When restricting the sample to those between the ages of 6-20, we find that wages for those under 14 drop by nearly 4\%, whereas for the sample between ages 6-30 we find the wage drop to be nearly $10 \% .^{23}$

\subsection{Effect of the ban on child labor}

We now turn to the impact of the ban on its intended target - child labor. This involves estimating equation (2) using a child employment dummy as the outcome instead of wages. The results of this estimation for various age samples and sectors are displayed in Table 4 . The likelihood of child employment relative to non-child employment increases by 1.7 to 1.9 percentage points due to the ban, depending on the age range used. Using the narrow age band estimate, this implies that child labor has increased $12.5 \%$ over the pre-ban mean. ${ }^{24}$

While relative labor participation for those below 14 increases in both sectors, the largest increase is in agriculture (columns 5 and 6). Combined, these sector-level results are consistent with the partial mobility case of the two-sector model where the ban leads to perverse effects; postban manufacturing wages are still high enough that children continue to work in manufacturing and yet there are barriers that restrict entry into manufacturing so that much of the increase in child labor occurs in agriculture.

The two sector model in the previous section also generates additional predictions about which households are most likely to increase child labor after the ban. Because the ban causes child wages to fall relative to adult wages, households with working children pre-ban are even more perversely affected. In the model, all households face lower income due to the fall in adult wages resulting from the ban but households with working children should exhibit larger negative effects of the ban relative to households with children over the legal working age. Thus our empirical

\footnotetext{
${ }^{23}$ Note that the estimated effect of the ban on overall wages may not be a simple weighted average of the effect on individual sectors, as the former also takes into account changes in the composition of the workforce. For example, if the ban results in larger increases in child employment in agriculture than in manufacturing (which we find), then the overall average wage effect will reflect a larger decrease in child wages than the average of the individual sector effects because relatively more working children are earning the low agricultural wages post-ban.

${ }^{24}$ Note that throughout this period, labor force participation of those between the ages of 6-20 or 6-17 is falling. Hence, the parallel trends assumption for the employment specifications is that were it not for the ban, labor supply of those below 14 would have fallen by as much as those just above 14. This is important because the summary statistics shown in Table 1 will reveal that overall rates of child labor has fallen during the sample period, but this should not be interpreted as a positive outcome of the ban.
} 
strategy is built around the notion that a child's employment status will respond to the ban through its effect on sibling wages; a child whose sibling is below the legal working age will suffer a larger drop in household income and thus be more likely to work than a child whose sibling is above the legal working age. This sibling-based identification is crucial to our analysis of the effect of the ban because while the more straightforward difference-in-difference approach (equation 2) gives an estimate of the overall impact of the ban on child employment, it cannot identify the overall impact of the ban on any household-level outcome. This is because we know from the general equilibrium model of the previous section that all households are impacted by the ban; thus at the household level, we have no sample of "control" households who are unaffected by the ban. ${ }^{25}$

The heart of our identification lies in the fact that the Child Labor Act of 1986 banned or limited employment of children less than 14 years of age. We use this rule as the building block of our sibling-based difference-in-difference strategy. In the absence of the ban, families with a 12-13 year old working child should be very similar to those with a 14-15 year old working child. However, once the ban is in place, the 12-13 year old will earn lower wages and his/her family may need to send another child to work. The 14-15 year old may also suffer a drop in wages due to the general equilibrium effects of the ban but as illustrated in the previous section, the fall in wages should be relatively larger for children under 14 and thus the labor responses should be concentrated in families with children under 14. Therefore the identification in our empirical strategy comes from comparing the employment outcomes of children with siblings who are below or above age 14 , both before and after the ban is in place. Our sibling-based specification is

$$
\begin{aligned}
& Y_{i t}=\beta_{1} \text { Treatment }_{i}+\beta_{2} *{\text { Post } 1986_{t}} \\
& \left.+\beta_{3} \text { (Treatment }_{i} \times \text { Post } 1986_{t}\right)+\beta_{X} X_{i t}+\delta_{t}+\varepsilon_{i t}
\end{aligned}
$$

where $Y_{i t}$ is a child-level outcome, most often a dummy variable for whether the child $i$ in survey round $t$ is employed although we also examine other child outcomes such as schooling status to

\footnotetext{
${ }^{25}$ See Bugni (2012) for a nice example of the issues encountered while estimating difference in difference models when the "control" group is also affected. Our wage results however, confirm that even if there are spillovers of the effect of the ban to those above 14, the spillovers are in the direction that would lead us to an overall underestimate.
} 
study how the ban impacts child time allocation and human capital formation. ${ }^{26}$ Post $1986_{t}$ is an indicator variable for survey rounds occurring after the Child Labor Act in 1986; $X_{i t}$ is a vector of household- and child-level covariates such as family size, household head characteristics, gender, and state-region fixed effects ${ }^{27} ; \delta_{t}$ is a survey-round fixed effect.

Treatment $t_{i}$ is a dummy variable taking the value of 1 when the child has at least one sibling who is both underage in the eyes of the law and working age, which we define to be a sibling of age 10-13; the treatment dummy is 0 when a child has a sibling in the age range 1425 or below the age of 9 . We choose this age range because the treatment is intended to isolate families affected by the ban - specifically those with children below the age of 13 and likely to be working before the ban. Since only $2 \%$ of children under the age of 10 are working before the ban as compared to $14 \%$ in the age range 10-13 (see Table $1 \mathrm{~b}$ ), we believe that a child with a sibling in this age range is much more likely to be affected by the ban than a child with any sibling under the age of 13 .

Our coefficient of interest is $\beta_{3}$, which captures the differential increase in the likelihood a child is employed after the ban is in place, for children with working age siblings most likely to be affected by the ban versus children with siblings too young to be working or too old to be affected by the ban. In other words, $\beta_{3}$ identifies the causal effect of the ban through the channel of sibling wages, which is over and above the effect of the ban through adult wages experienced by all households. We therefore expect the estimates of $\beta_{3}$ to be smaller than the overall estimated effect of the ban on employment (displayed in Table 4), which captures both the sibling wage channel and the adult wage channel. The standard errors for the sibling-based estimates are clustered at the family-level, as the "treatment" of having a sibling in the right age range to be affected by the ban

\footnotetext{
${ }^{26}$ Ideally, we would observe child labor on both the intensive (hours worked) and extensive margin (labor force engagement) since families may respond to the ban by increasing both the hours each child works and the number of working children. However, the survey collects information only on the extensive margin so we can only consider the effects of the ban on whether a child is employed.

${ }^{27}$ Although the control set varies by specification, most regressions include controls for child gender and age fixed effects, family size, gender and age of household head, a dummy variable for urban status, state-region fixed effects, household type fixed effects, religion fixed effects, household head's education level fixed effects, household head's industry fixed effects. See notes below each table for a full list of included covariates. Results with a more extensive set of demographic controls can be found in Online Appendix Table 9
} 
is at the household- rather than child-level. ${ }^{28}$ In a sense, $\beta_{3}$ captures an "Intent-to-treat" effect of the ban because we define "Treatment" in (3) as having a sibling who is both underage relative to the law and likely to be working. ${ }^{29}$

Table 5 displays the results for estimating our baseline specification in (3) on three age groups: the very young (age 6-9), the young (10-13) and older children (14-17). The estimated effect of the ban is to increase relative employment among children under the age of 14. Having an underage sibling leads to a 0.3 percentage point increase in the likelihood of engaging in work after the ban for the very young. While this point estimate is small, it is both statistically and economically significant; the pre-ban proportion of children employed in that age range is only 2 percent so the effect of the ban is to increase employment by $15 \%$ over the mean for this group. The ban increases the probability of employment by 0.8 percentage points ( $5.6 \%$ over the mean) for young children ages 10-13. However, older children ages 14-17 overall are unaffected by the ban. The effect for this group is both small relative to the mean and statistically insignificant. ${ }^{30}$ Again, the largest increase in child labor is in agriculture (columns 4 and 5) which is consistent with the partial mobility case of the two-sector model where there is restricted entry into manufacturing.

5.2.1. Results by Poverty. Another important source of heterogeneity in treatment comes from the economic status of the household. As outlined in the previous section, the driving force behind families' decision to employ their children is the need to reach subsistence levels of consumption. Those who are most likely to resort to child labor before the ban and thus be affected by the ban are those with low incomes. Unfortunately we do not observe household income in the data. We

\footnotetext{
${ }^{28}$ Our results are also robust to clustering at the region-year, state-year, region and state levels. Results not shown but are available upon request.

${ }^{29}$ In our baseline sample, we include all children with siblings in the 10-25 age range, but our results are robust to restricting the sample to those with siblings just above and below the age of 14. Results not shown but are available upon request.

${ }^{30}$ In reality, since only $14 \%$ of children ages $10-13$ are working before the ban, the effect of the ban on truly "treated" families (those with working children ages 10-13) could be much larger. By altering our definition of "Treatment" to include only those children who have siblings under 14 working in manufacturing (the sector affected by the Act of 1986), we can identify a more focused "Intent-to-Treat" effect. This "narrow" definition isolates families who we believe are the most likely to be affected by the ban, although we cannot distinguish between families who had children working in manufacturing before the ban from those whose children began working as a consequence of the ban. With this narrower definition of treatment we find (as expected) larger point estimates. These tables are shown in the Online Appendix.
} 
therefore rely on two important proxies: education of the household head and non-staple share of foods consumed.

Table 6a shows that almost all of the overall labor increase in child labor from the siblingbased treatment come from the households with less educated household heads. The response from households with educated household heads is small and statistically insignificant. Note that the pre-ban means for child labor participation are much higher in households with a less educated head and this is very much in line with the model.

Table $6 \mathrm{~b}$ shows similar results when we examine families that consume at different points on the non-staple food share distribution. Since non-staple share of food is a positive measure of wealth and welfare as established by Jensen and Miller (2010), we see that families with high staple share of food consumption are the families likely to see the increases in child labor after the ban. The non-staple share also most closely captures households near subsistence taking into account different household demographics and caloric needs et cetera.

\subsection{Substitution from schooling}

Table 7 shows the overall effect of the ban on child schooling status (column 1) as well as the sibling-based effect for various age groups (columns 2-4). The results in column 1 indicate that the ban had no overall effect on child schooling status. ${ }^{31}$ The sibling-based effects indicate that the increases in employment for children found in Table 5 are offset by decreases in schooling enrollment in the 10-13 age range. In other words, for households who are most affected by the ban, there is close to a one-to-one reduction in schooling corresponding to the increase in employment. $^{32}$

It is important to note that schooling and work are not the only activities that children may engage in. There is a substantial literature on "idle" children, i.e. those who report neither being in school nor in economic activities (see for example Edmonds and Pavcnik (2005a), Biggeri et al. (2003) and Bacolod and Ranjan (2008)). Fortunately, the IPUMS data are quite detailed and

\footnotetext{
${ }^{31}$ Note that when considering current schooling status (whether or not currently in school), we are restricted to samples of school-going age children only because the outcome is not relevant for older populations. Thus we only present the results of estimating equation 2 for the narrowest age band, 10-17.

${ }^{32}$ Unfortunately, our data does not allow us to compute an hour to hour substitution to make our estimates comparable to Boozer and Suri (2007).
} 
provide a fairly exhaustive list of primary activities for children above 5 years of age (respondents are forced to choose a primary activity for each child). As discussed in Edmonds et al. (2010), policies affecting child labor may also impact idleness of children. The results in Tables 5 and 7 suggest a complete switching of activities for children ages 10-13 due the sibling-based effect, as the increase in employment is offset by the decrease in schooling. When we further examine the effect of the ban on other outcomes (results not shown but available upon request), we find that the ban has no statistically significant impact on children's housework (time spent on domestic chores in own household, not working in others' households or home enterprises) or likelihood of being ill or disabled.

\subsection{Effect of the ban on household expenditure and consumption}

We next turn to the impact of the child labor ban on various indicators of household welfare. The theoretical model implies that households only use child labor to reach some minimum level of consumption, so households that are affected by the ban but are able to increase child labor supply would experience no drop in consumption. However, the net effect of lower wages for child labor and higher child labor provision on household income and consumption in our empirical context is unclear for several reasons. First, households that are unable to increase child labor supply could experience a decline in consumption to below "subsistence" levels. Second, if one of the responses to the ban was a shift from manufacturing wage labor to real/fake household enterprise labor, we cannot observe the implicit wage (the revenue marginal product of child labor in the household enterprise production function) and whether it declines like the market wage following the ban. Third, if households have other mechanisms for dealing with a drop in income due to the child labor ban, such as selling assets or reallocating their expenditures across different types of goods, we may observe the effect of the child labor ban along some dimensions (declining assets, declining expenditures, or declining food quality) but not along others (such as the per capita calorie intake of the household).

Our approach is thus to look at changes along multiple components of household welfare for households that are more or less affected by the ban. We construct five household-level welfare measures as described in the data section. Our first measure, per capita expenditure, is one of the 
most widely used indicators of household welfare and is used for Indian and global poverty measurement. Our second measure, per capita food expenditure, is highly correlated with per capita expenditure (0.92) but may vary if poor households adjust to shocks by lowering non-food intake more than food intake. Our third measure, caloric intake per capita, is moderately correlated with food expenditure per capita (0.54) but can vary if households adjust to a drop in food expenditure by switching from foods that are more expensive per calorie to foods that are cheaper per calorie. Our fourth measure, the staple share of calories, is proposed by Jensen and Miller (2010) as a measure of household nutritional adequacy in the presence of caloric needs that are unknown or variable across households. Their logic is that if households attach a high disutility to having caloric intake below caloric needs, they will substitute towards the cheapest sources of calories (staples). The staple share is thus an inverse indicator of household welfare, and consistent with this we find a negative correlation (-0.57) with per capita expenditures. Finally, our fifth measure is a household asset index constructed as the principal component of a set of variables that capture the quality and quantity of housing, the type of energy used for cooking and lighting, and the quantity of electricity used (which is likely to be correlated with the number of appliances and durables used by the household). If households adjust to negative income shocks by selling assets, using electric appliances less intensively, or letting the quality of their assets deteriorate then we might expect deterioration in the asset index for households affected by the ban. While the asset index is correlated with per capita expenditures (0.50) and other flow measures of welfare, it uses an entirely different source of variation across households. Thus while measurement error may be correlated across the other measures, it is unlikely to be correlated across our expenditure/consumption flow measures and our asset measure.

Given that our welfare measures are at the household level, we define treatment as the presence of a child aged 10-13 with non-treated households consisting of households with children aged $0-9$ or $14-25 .^{33}$ Note that although we control flexibly for many aspects of household demographics in our specification, we are specifically comparing households with different demographics and hence different consumption needs (particular for calories). However, the coefficient

\footnotetext{
${ }^{33}$ We provide employment estimates using this definition and at the household level in Online Appendix Table 4.
} 
of interest is not the coefficient on treatment but the interaction of treatment with the post-ban dummy variable - thus while households with younger or older children may have systematically different caloric needs and differ in their consumption patterns along multiple dimensions, it is the change in this difference pre vs. post ban that identifies the effect of the ban on our household welfare outcomes. One issue that does concern us is the possibility that changes in child labor supply induced by the ban may affect household caloric intake and consumption patterns not through the income side but through an increased demand for calories due to higher activity levels. ${ }^{34}$ We would expect this to amplify the effect of lower child wages on household welfare further, but it could imply constant or increased caloric intake despite constant or declining household income and expenditures. However, a change in caloric needs for treated households would still be reflected in a rise in the staple share of calories - the Jensen and Miller (2010) framework suggests that if the ban affects both income and consumption needs (through the effect on labor supply), the staple share will still be a reliable indicator of the net effect on household welfare.

The results from our first specification are reported in Table 8. We find a negative and statistically significant point estimate of the ban's effect on four out of five welfare measures. The one exception is caloric intake per capita which has a positive but not statistically significant coefficient. This is consistent with households near-subsistence - the ones likely to be most affected by the ban - being unable to cut back on calories and instead reducing other aspects of household welfare (consuming more less tasty staples or selling assets) as well as the idea that increased child labor for these households may increase household caloric requirements and thereby constrain households from adjustment on this margin. However the changes for all of the welfare measures are quantitatively small - about 0.01 standard deviations of the pre-ban cross-section - and the standard errors are small enough to rule out large positive or negative effects of the ban. ${ }^{35}$

\footnotetext{
${ }^{34}$ See Li and Eli (2013) for an exploration of this link using Indian Time Use Data.

${ }^{35}$ When we consider a narrower definition of the comparison group in Table 3 of the Online Appendix (or restricting to households with children aged 6-9 or 14-17) we find similarly small results.
} 


\section{ROBUSTNESS CHECKS}

\subsection{Measurement error and misreporting}

As described in Section 4, there is scope for measurement error in the reporting of child activities, especially with respect to child labor. In particular parents may underreport the labor of their children due to social or other types of pressure. Moreover it is possible that this underreporting increases differentially for children under the legal working age of 14 after the ban on child labor. Such underreporting should go against our results in that it would lead us to show lower levels of child labor.

Families may circumvent the law by misreporting age rather than work status. We address this concern in Figures 14 and 15 of the Online Appendix. If parents strategically report their children as being older in order to justify their employment we should see distinct jumps in reported age of children, particularly from age 13 to 14 . However, we do not observe a larger jump in age reporting at 14 versus 13 after the ban is in place (neither in overall nor for children employed in manufacturing), thus it appears that the ban does not impact misreporting by parents.

\subsection{Falsification exercises}

The underlying assumption for our identification strategy is that the difference between children with siblings just above and below the legal working age should be steady across time in the absence of the ban. One way to test whether the changes in child employment were due to ban and not some other change occurring at the same time is to impose "false" age restrictions on our untreated sample. In Appendix Table A.1 we see that when we define treatment as having a very young sibling (ages 0-4), we find no such effect of the ban (column 2); the same can be said when we define treatment as having sibling of ages $15-19$ or 20-25. The results of this "placebo" test leads us to believe that our estimated effect of the ban is not picking up the effect of having an older or younger sibling.

One of the main assumptions in our model is that adults supply labor inelastically. Hence, in response to lower child wages, we should not expect to see a response from adults. In Table 5 in the Online Appendix, we show that this is precisely the case. Men and women in the age range 
18-55 do not show any increases or decreases in labor supply in response to the ban. Note that "treatment" here is defined as having a child under the age of 14 in the household, and note it is slightly different in interpretation from the previous tables where we refer to these children and their "siblings."

In Table 6 of the Online Appendix we show that estimating our main specification but using 1993 as the "post" year and 1987 as the "pre" year does not lead to significant and positive coefficients. Hence, it appears that the policy change specific to 1986 is driving our results. In addition, we wish to mention that our results are also robust to the use of sampling weights and flexible controls for household demographics. These tables are presented in the Online Appendix.

\subsection{Economic growth and skill-biased technical change}

One potential explanation for our finding that child wages drop relative to adult wages is a wage-earning workforce composition effect due to the rapid economic growth India experienced during the period under study. In section 3 we assume that all children are equally productive and earn the same wage. However, given the observation that child employment and wages are generally increasing in age, we might expect households to withdraw the least economically productive children first as their incomes rise. If the youngest children are less productive then we would expect economic growth to lead to a a convergence of child and adult wages; however, that is not the case.

Our sectoral evidence - higher relative employment by young children in agriculture with no change in relative wages, and lower relative wages for young children in manufacturing with no change in relative employment - also indicates that this type of wage-earning workforce composition effect is unlikely to be driving our wage results. Finally, we can additionally control for state-level economic indicators and their interaction with our indicator for being under 14 (or having a sibling ages 10-13 for sibling-based effects). This allows state-level economic growth to influence the wages and employment of those under 14 differently than those above the legal working age. If state-level economic growth leads to compositional changes of the under-14 workforce relative to the over-14 workforce, then the results shown in Appendix Table A.2 indicate these compositional changes are not driving our wage or employment results. 
Another alternate explanation for our wage results could be that the results capture an average decline in wages for children due to skill-biased technical change. If skills are positively correlated with age, we one might expect that skill-biased technical change may reduce wages more for younger individuals (under 14) than older individuals (over 14), leading to decreases in wages and increases in child labor independent of the ban. To rule out this possibility we refer to our results in Appendix Tables A.3 and A.1. Here we can see that our results hold even when we allow for the age gradient to change after the ban is in place by including interactions between age and time (Appendix Table A.3). This should capture changes to the return to skill (and thus age) between the pre-ban and post-ban periods. Moreover child labor only increases for children who have siblings under the official age limit of 14; increased work is not the consequence of having a younger sibling more generally (Appendix Table A.1).

\subsection{Other state and national policies}

Importantly, other labor laws that would be pertinent to our case did not have age specific restrictions and were passed before 1983. The Bonded Labour System (abolition) Act was passed in 1976, the Contract Labour (regulation and abolition) Act in 1970 and the Inter-State Migrant Workmen's Act in 1979. Using Besley and Burgess's (2004) state level changes to the Industrial Disputes Act of 1947 that classify states as pro-worker, pro-employer or neutral, we find that only 3 out of 16 states in their sample changes classification between 1983-1994. We account for all other temporal and spatial differences in laws and other factors by using survey-year and state fixed effects, and our results are also robust to controlling for state by year fixed effects (see Table A.4). Ultimately, any other factor that would be confounding in our case would have to be one that differentially affects those under 14 and was implemented between 1983-1994 at the national level as our identification is built on the difference in changes in employment and wages for those above and below age 14 .

One such policy that deserves further attention is the National Policy on Education that was amended and implemented in $1986 .{ }^{36}$ This policy sought to improve educational achievement

\footnotetext{
${ }^{36}$ Our thanks to Anjini Kochar for pointing this out.
} 
and enrollment for all ages, with a particular focus on primary education via "Operation Blackboard" (see Chin (2005) for more details). What implications does this policy have for our results? First, any effect of school improvements should lead us to find lower levels of child employment and higher levels of school enrollment; hence, to the extent that education policy was drawing child away from the labor market, our results can be interpreted as a lower bound. Second, we show that our results are unchanged by restricting our sample to states less affected by "Operation Blackboard" in Online Appendix Table 7.

\section{CONCLUSION}

This paper is the first empirical investigation of the impact of India's most important legal action against child labor. While the Child Labor (Prohibition and Regulation) Act of 1986 prevented employers from employing children in certain sectors and increased regulation of child labor in non-family run businesses, the net result of this ban appears to be an increase in child labor in some families. We find that child wages decrease in response to such laws and poor families send out more children into the workforce. Due to increased employment, affected children are less likely to be in school. These results are consistent with a two sector model with some frictions on mobility across sectors where the ban is more stringently enforced in one sector than the other. Importantly, we also examine the overall welfare effects of the ban on households. Along various measures of household consumption and expenditure, we find that the ban leads to small decreases in household welfare.

This paper does not intend to suggest that all child labor bans are useless. In fact, well formulated and implemented bans could absolutely help in eliminating child labor; ${ }^{37}$ but as we do in this case, research would have to examine how a decrease in child labor affects child and household welfare (Baland and Robinson (2000); Beegle, Dehejia and Gatti (2009)). To echo the reasoning in Basu (2004): "Legal interventions, on the other hand, even when they are properly enforced so that they do diminish child labor, may or may not increase child welfare. This is one

\footnotetext{
${ }^{37}$ One way of achieving this in our context might be to increase fines and penalties to a point where employers no longer hire child labor.
} 
of the most important lessons that modern economics has taught us and is something that often eludes the policy maker."

In the particular case of the 1986 ban, this paper has shown that households are worse off along measures that reflect welfare. Not only is the ban ineffective in the short run (by not increasing household welfare and by not decreasing child labor), it can have perverse long run consequences by affecting human capital investments, asset accumulation and perhaps also affecting fertility. Future research on child labor bans could focus on some of these long run effects. There are many options available to policy makers who wish to reduce the incidence of child labor (like cash transfers, increasing investments in and returns to education, etc). If anything, we think a discussion in policy circles about these alternatives should be heightened since it appears from our study that child labor bans of the type instituted under the Child Labor (Prohibition and Regulation) Act can be ineffective. Our results highlight the importance of taking into account weak enforcement and behavior at the margin of subsistence when formulating important policies in developing countries. 


\section{REFERENCES}

Bacolod, M. P. and P. Ranjan (2008). Why children work, attend school, or stay idle: the roles of ability and household wealth. Economic Development and Cultural Change 56(4), 791-828.

Basu, K. (1999). Child labor: cause, consequence, and cure, with remarks on international labor standards. Journal of Economic Literature 37(3), 1083-1119.

Basu, K. (2005). Child labor and the law: Notes on possible pathologies. Economics Letters 87(2), $169-174$.

Basu, K., G. Genicot, and J. Stiglitz (1998). Household labor supply, unemployment, and minimum wage legislation. World Bank Policy Research Working Paper (2049).

Basu, K. and P. H. Van (1998). The economics of child labor. American Economic Review, $412-$ 427.

Besley, T. and R. Burgess (2004). Can labor regulation hinder economic performance? evidence from india. The Quarterly Journal of Economics 119(1), 91-134.

Bhalotra, S. (2007). Is child work necessary? Oxford Bulletin of Economics and Statistics 69(1), $29-55$.

Bhalotra, S. and C. Heady (2003). Child farm labor: The wealth paradox. The World Bank Economic Review 17(2), 197-227.

Biggeri, M., L. Guarcello, S. Lyon, and F. C. Rosati (2003). The puzzle of "idle" children: Neither in school nor performing economic activity: Evidence from six countries. Understanding Children's Work Project draft working paper, August.

Boockmann, B. (2010). The effect of ilo minimum age conventions on child labor and school attendance: Evidence from aggregate and individual-level data. World Development 38(5), 679692.

Boozer, M. and T. Suri (2007). Child labor and schooling decisions in ghana. MIT Working Paper.

Chin, A. (2005). Can redistributing teachers across schools raise educational attainment? evidence from operation blackboard in india. Journal of Development Economics 78, 384-405.

Commons, J. R. (1924). Law and economics. Yale Law Journal 34, 371.

Das, R. K. (1933). Child labour in india: I. Int'l Lab. Rev. 28, 796. 
Doran, K. (2013). How does child labor affect the demand for adult labor? evidence from rural mexico. Journal of Human Resources 48(3), 703-735.

Edmonds, E. V. (2007). Child labor. Handbook of development economics 4, 3607-3709.

Edmonds, E. V. and N. Pavcnik (2005a). Child labor in the global economy. The Journal of Economic Perspectives 19(1), 199-220.

Edmonds, E. V. and N. Pavcnik (2005b). The effect of trade liberalization on child labor. Journal of International Economics 65(2), 401-419.

Edmonds, E. V., N. Pavcnik, and P. Topalova (2010). Trade adjustment and human capital investments: Evidence from indian tariff reform. American Economic Journal: Applied Economics $2(4), 42-75$.

Edmonds, E. V. and M. Shrestha (2012). Impact of minimum age of employment regulation on child labor and schooling. IZA Journal of Labor Policy 1(14), 2-28.

Gopalan, C., B. Rama Sastri, and S. Balasubramanian (1980). Nutritive Values of Indian Foods (3rd edition). Hyderabad: National Institute of Nutrition, Indian Council of Medical Research.

Government of Gujarat (2004). Performance review chapter iii. Civil Audit Report.

Human Rights Watch (1996). The small hands of slavery: Bonded child labor in india. Human Rights Watch Children's Rights Report.

Human Rights Watch (2003). Small change: Bonded child labor in india's silk industry. Human Rights Watch Special report.

International Labour Organization (2013). Marking progress against child labour - global estimates and trends 2000-2012. ILO Report.

Jafarey, S. and S. Lahiri (2002). Will trade sanctions reduce child labour?: The role of credit markets. Journal of Development Economics 68(1), 137-156.

Jensen, R. T. and N. H. Miller (2010). A revealed preference approach to measuring hunger and undernutritiono. NBER Working Paper (16555).

Li, N. and S. Eli (2013). Can caloric needs explain three food consumption puzzles? evidence from india. Working Paper. 
Lleras-Muney, A. (2002). Were compulsory attendance and child labor laws effective? an analysis from 1915 to 1939. The Journal of Law \& Economics 45, 401-691.

Manacorda, M. (2006). Child labor and the labor supply of other household members: Evidence from 1920 america. The American Economic Review 96(5), 1788-1801.

Moehling, C. M. (1999). State child labor laws and the decline of child labor. Explorations in Economic History 36(1), 72-106.

Ramanathan, U. (2009). Evolution of the law on child labor in india. The world of Child labor. An historical and regional Survey.

Skoufias, E., S. W. Parker, J. R. Behrman, and C. Pessino (2001). Conditional cash transfers and their impact on child work and schooling: Evidence from the progresa program in mexico [with comments]. Economia 2(1), 45-96.

Solon, G., S. J. Haider, and J. Wooldridge (2013). What are we weighting for? NBER Working Paper No. 18859, February.

Stigler, G. J. (1992). Law or economics? Journal of Law and Economics 35(2), 455-468.

Sunstein, C. R. (1994). Political equality and unintended consequences. Columbia Law Review 94(4), 1390-1414.

Swinnerton, K. A. and C. A. Rogers (1999). The economics of child labor: Comment. The American Economic Review 89(5), 1382-1385.

Thirumurthy, H., J. Zivin, and M. Goldstein (2007). Aids treatment and intrahousehold resource allocations: Children's nutrition and schooling in kenya. Center for Global Development Working Paper (105).

Weiner, M. (1991). The child and the state in India: Child labor and education policy in comparative perspective. Princeton University Press. 


\section{TABLES}

TABLE 1A. Summary statistics: Means of household variables

\begin{tabular}{lcc}
\hline \hline & 1983 & 1987,1993 \\
\hline Family Size & 6.202 & 5.968 \\
HH Head is Male & 0.915 & 0.918 \\
HH Head Age & 43.613 & 43.064 \\
HH Head Completed Secondary School & 0.098 & 0.135 \\
HH Head is in Agriculture & 0.509 & 0.499 \\
HH Head is in Manufacturing & 0.361 & 0.392 \\
Hindu & 0.835 & 0.831 \\
Nuclear family household (no extended family) & 0.562 & 0.608 \\
Urban & 0.233 & 0.236 \\
\hline Number of Observations & 72,276 & 136,510 \\
\hline \hline
\end{tabular}

TABLE 1B. Summary statistics: Means of child variables

\begin{tabular}{|c|c|c|c|c|c|c|c|c|}
\hline & \multicolumn{4}{|c|}{1983} & \multicolumn{4}{|c|}{1987,1993} \\
\hline & All ages & Ages 6-9 & Ages 10-13 & Ages 14-17 & All Ages & Ages 6-9 & Ages 10-13 & Ages 14-17 \\
\hline Age & 10.934 & & & & 10.985 & & & \\
\hline Male & 0.528 & 0.518 & 0.533 & 0.535 & 0.535 & 0.525 & 0.537 & 0.548 \\
\hline Mother Completed Secondary School* & 0.032 & 0.035 & 0.029 & 0.029 & 0.057 & 0.057 & 0.056 & 0.060 \\
\hline Number of Siblings Ages 7-17 & 1.932 & 1.829 & 2.016 & 1.964 & 1.787 & 1.685 & 1.923 & 1.751 \\
\hline Employed $(1=$ Yes, $0=$ No) & 0.148 & 0.020 & 0.142 & 0.336 & 0.117 & 0.012 & 0.096 & 0.288 \\
\hline Number of Observations & 177,965 & 65,685 & 63,761 & 48,519 & 336,724 & 121,440 & 118,243 & 97,041 \\
\hline
\end{tabular}

Mother's age and educational attainment are not available for all child observations. Real wage statistics are conditional on paid employment. 
TABLE 2. Summary statistics: Consumption and expenditure measures

\begin{tabular}{lcccccc}
\hline \hline & \multicolumn{3}{c}{1983} & \multicolumn{3}{c}{1987,1993} \\
& Obs. & Mean & Std. Dev. & Obs. & Mean & Std. Dev. \\
& $(1)$ & $(2)$ & $(3)$ & $(4)$ & $(5)$ & $(6)$ \\
\hline Ln(per capita expenditure) & 111554 & 4.71 & 0.58 & 242871 & 4.78 & 0.56 \\
Ln(per capita food exp.) & 110275 & 5.11 & 0.52 & 242768 & 5.19 & 0.49 \\
Ln(calories) & 111286 & 7.64 & 0.52 & 242055 & 7.64 & 0.47 \\
Staple share & 111532 & 0.69 & 0.18 & 242092 & 0.66 & 0.18 \\
Asset Index & 113586 & -0.91 & 2.02 & 242852 & -0.20 & 2.32 \\
\hline \hline
\end{tabular}

TABLE 3. Effect of Ban on Child Wages

Dependent Variable: Log(Real Wages)

\begin{tabular}{|c|c|c|c|c|}
\hline & $\begin{array}{c}\text { All Sectors } \\
\text { Ages 6-30 } \\
\text { (1) }\end{array}$ & $\begin{array}{l}\text { All Sectors } \\
\text { Ages 6-20 } \\
\text { (2) }\end{array}$ & $\begin{array}{l}\text { Manufacturing } \\
\text { Ages 6-30 } \\
\text { (3) }\end{array}$ & $\begin{array}{c}\text { Agriculture } \\
\text { Ages 6-30 } \\
\text { (4) }\end{array}$ \\
\hline Under14*Post1986 & $\begin{array}{c}-0.100 * * * \\
(0.036)\end{array}$ & $\begin{array}{c}-0.038^{* *} \\
(0.018)\end{array}$ & $\begin{array}{c}-0.048^{* *} \\
(0.023)\end{array}$ & $\begin{array}{l}-0.008 \\
(0.014)\end{array}$ \\
\hline Observations & 100,394 & 33,038 & 60,257 & 40,137 \\
\hline R-squared & 0.546 & 0.375 & 0.493 & 0.366 \\
\hline
\end{tabular}

$* * * \mathrm{p}<0.01,{ }^{* *} \mathrm{p}<0.05, * \mathrm{p}<0.1$ All regressions include a dummy for Post-1986, a dummy for "Under 14 " as well as controls for gender, family size, age of household head, sector dummy (agricultural or manufacturing), age fixed effects, gender of household head, urban status, survey year fixed effects, state-region fixed effects, hh type fixed effects, religion fixed effects, household head's education level fixed effects, household head's industry fixed effects. "Under 14" is a dummy variable that takes the value of 1 if the child is under 14 years of age. Sample consists of all individuals who are currently employed in paid jobs and are related to the household head. Standard errors are clustered by age-year. Real wages are nominal wages deflated by the average wholesale price index reported by the Government of India for the respective year. Sample only contains respondents with non-zero wages, trimmed at the $1 \%$ and $99 \%$ percentiles. 
TABLE 4. Overall Effect of Child Labor Ban on Employment

Dependent Variable: Employed

\begin{tabular}{lcccccc}
\hline & \multicolumn{2}{c}{ All Sectors } & \multicolumn{2}{c}{ Manufacturing } & \multicolumn{2}{c}{ Agriculture } \\
\hline & Ages 6-20 & Ages 10-17 & Ages 6-20 & Ages 10-17 & Ages 6-20 & Ages 10-17 \\
& $(1)$ & $(2)$ & $(3)$ & $(4)$ & $(5)$ & $(6)$ \\
\hline Under14*Post1986 & $0.019^{* *}$ & $0.017^{* * *}$ & $0.004^{* *}$ & $0.005^{* * *}$ & $0.016^{* *}$ & $0.013^{* * *}$ \\
& $(0.008)$ & $(0.005)$ & $(0.002)$ & $(0.001)$ & $(0.006)$ & $(0.004)$ \\
\hline $\begin{array}{l}\text { Mean of Dep. Var. } \\
\text { (for children under 14) }\end{array}$ & 0.080 & 0.141 & 0.014 & 0.027 & 0.079 & 0.140 \\
Observations & 644,893 & 332,282 & 643,312 & 331,447 & 0.065 & 0.114 \\
R-squared & 0.256 & 0.172 & 0.142 & 0.101 & 0.205 & 0.164 \\
\hline \hline
\end{tabular}

*** $\mathrm{p}<0.01, * * \mathrm{p}<0.05, * \mathrm{p}<0.1$ See notes under Table 3. Sample consists of all individuals in specified age range who are related to the household head.

TABLE 5. Sibling-based Effects of the Ban on Child Employment

Dependent Variable: Employed (1=Yes, $0=$ No)

\begin{tabular}{lccccc}
\hline & \multicolumn{3}{c}{ All Sectors } & Agriculture & Manufacturing \\
\hline & Ages 6-9 & Ages 10-13 & Ages 14-17 & Ages 10-13 & Ages 10-13 \\
& $(1)$ & $(2)$ & $(3)$ & $(4)$ & $(5)$ \\
\hline Treatment*Post1986 & $0.003^{* * *}$ & $0.008^{* * *}$ & -0.002 & $0.006^{* *}$ & 0.002 \\
& $(0.001)$ & $(0.003)$ & $(0.005)$ & $(0.002)$ & $(0.008)$ \\
\hline Pre-Ban Mean of Dep. Var. & 0.020 & 0.142 & 0.336 & 0.115 & 0.027 \\
Observations & 187,126 & 182,005 & 145,562 & 181,712 & 181,712 \\
R-squared & 0.025 & 0.098 & 0.180 & 0.104 & 0.045 \\
\hline \hline
\end{tabular}

*** $\mathrm{p}<0.01, * * \mathrm{p}<0.05, * \mathrm{p}<0.1$ All regressions include a dummy for Post-1986, a dummy for "Treatment" as well as controls for gender, family size, age of household head, age fixed effects, gender of household head, urban status, survey year fixed effects, state-region fixed effects, hh type fixed effects, religion fixed effects, household head's education level fixed effects, household head's industry fixed effects. Sample of children consists of all who are related to the household head, excluding any who are the household head or the spouse of the household head. "Treatment" is a dummy variable that takes the value of 1 if the child has a sibling who is between the ages of 10 and 13 (inclusive) and takes on a value of 0 if sibling is between ages of 14-25 (inclusive) or below the age of 9. Standard errors are clustered by household. 
TABLE 6A. Effects of Child Labor Ban on Child Employment by Education of HH Head

\begin{tabular}{lcccc}
\hline \hline & \multicolumn{2}{c}{ Overall Effects } & \multicolumn{2}{c}{ Sibling-based Effects } \\
\hline & HH Head Has & HH Head Has & HH Head Has & HH Head Has \\
& Less Than Sec. Ed. & At Least Sec. Ed. & Less Than Sec. Ed. & At Least Sec. Ed. \\
\hline & Ages 10-17 & Ages 10-17 & Ages 10-13 & Ages 10-13 \\
& $(1)$ & $(2)$ & $(3)$ & $(4)$ \\
\hline Treatment*Post1986 & 0.008 & -0.001 & $0.008^{* *}$ & -0.002 \\
& $(0.006)$ & $(0.003)$ & $(0.003)$ & $(0.003)$ \\
\hline Pre-Ban Mean & 0.154 & 0.017 & 0.155 & 0.017 \\
Observations & 277,663 & 54,619 & 153,145 & 28,860 \\
R-squared & 0.169 & 0.048 & 0.096 & 0.016 \\
\hline
\end{tabular}

*** $\mathrm{p}<0.01, * * \mathrm{p}<0.05, * \mathrm{p}<0.1$ "Treatment" for columns 1 and 2 is an indicator variable for under age 14. "Treatment" for remaining columns is an indicator variable for having a sibling aged 10-13 (inclusive). See notes under Tables 3 and 5.

TABLE 6B. Effects of Child Labor Ban on Child Employment by HH staple share of calories

\begin{tabular}{lcccc}
\hline \hline & \multicolumn{2}{c}{ Overall Effects } & \multicolumn{2}{c}{ Sibling-based Effects } \\
\hline & HH Has & HH Has & HH Has & HH Has \\
& High staple share & Low staple share & High staple share & Low staple share \\
\hline & Ages 10-17 & Ages 10-17 & Ages 10-13 & Ages 10-13 \\
& $(1)$ & $(2)$ & $(3)$ & $(4)$ \\
\hline Treatment & $0.016^{* * *}$ & 0.009 & $0.018^{* *}$ & $0.006^{*}$ \\
*Post1986 & $(0.006)$ & $(0.006)$ & $(0.008)$ & $(0.003)$ \\
\hline Pre-Ban Mean & 0.321 & 0.207 & 0.208 & 0.128 \\
Observations & 54,299 & 256,906 & 30,339 & 136,154 \\
R-squared & 0.211 & 0.167 & 0.137 & 0.092 \\
\hline \hline
\end{tabular}

$* * * p<0.01, * * p<0.05, * p<0.1$. High staple share refers to households with a staple share of calories higher than the pre-ban 75th percentile (0.834). Low staple share refers to the remaining $75 \%$ of households. "Treatment" for columns 1 and 2 is an indicator variable for under age 14. "Treatment" for remaining columns is an indicator variable for having a sibling aged 10-13 (inclusive). See notes under Tables 3 and 5 . 
TABLE 7. Effect of Ban on Child Enrollment in School

\begin{tabular}{lcccc}
\hline \hline & Overall Effect & \multicolumn{3}{c}{ Sibling-based Effect } \\
\hline & & & & \\
& Ages 10-17 & Ages 6-9 & Ages 10-13 & Ages 14-17 \\
& $(1)$ & $(2)$ & $(3)$ & $(4)$ \\
\hline Treatment*Post1986 & 0.004 & -0.004 & $-0.008^{*}$ & $0.010^{*}$ \\
& $(0.006)$ & $(0.005)$ & $(0.005)$ & $(0.005)$ \\
\hline Pre-Ban Mean of Dep. Var. & 0.559 & 0.545 & 0.557 & 0.375 \\
Observations & 331,692 & 186,722 & 181,667 & 145,327 \\
R-squared & 0.290 & 0.255 & 0.248 & 0.284 \\
\hline \hline
\end{tabular}

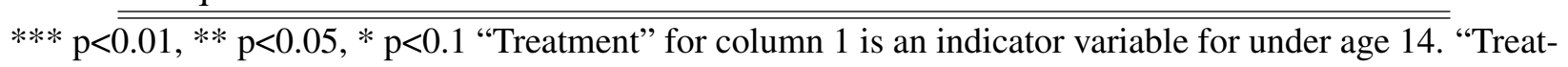
ment" for remaining columns is an indicator variable for having a sibling aged 10-13 (inclusive). See notes under Tables 3 and 5. 
TABLE 8. Effects on Household Consumption, Expenditure and Assets

\begin{tabular}{lccccc}
\hline \hline & \multicolumn{5}{c}{ Treatment=At least one child aged 10-13 } \\
\hline Dep. Var. & Log exp. pc & Log food exp. pc & Log cal. pc & $(1$-staple share) & Asset index \\
& $(1)$ & $(2)$ & $(3)$ & $(4)$ & $(5)$ \\
\hline Treatment*Post1986 & $-0.006^{*}$ & $-0.007^{* *}$ & 0.004 & $-0.005^{* * *}$ & $-0.025^{* *}$ \\
& $(0.003)$ & $(0.003)$ & $(0.003)$ & $(0.001)$ & $(0.012)$ \\
\hline Pre-ban Mean of Dep. Var. & 4.662 & 5.058 & 7.640 & 0.290 & -0.986 \\
Pre-ban S.D. of Dep. Var. & 0.537 & 0.484 & 0.422 & 0.164 & 1.975 \\
Observations & 299,423 & 298,313 & 299,545 & 299,555 & 301,262 \\
R-Squared & 0.483 & 0.396 & 0.167 & 0.526 & 0.604 \\
\hline \hline
\end{tabular}

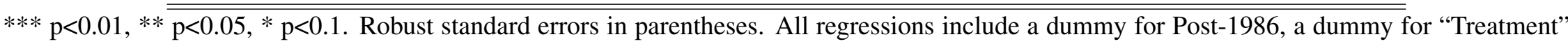
as well as household size fixed effects, number of children 0-5 fixed effects, number of children 6-17 fixed effects, number of adult female fixed effects, number of female children fixed effects, age of HH head, gender of HH head, urban status, survey year fixed effects, state-region fixed effects, religion fixed effects, HH head's education level fixed effects, HH head's industry fixed effects. Sample includes all households with at least one member under the age of 25 . 


\section{Appendix A. Appendix TABles}

TABle A.1. Falsification exercise 1: Imposing False Age Restrictions

\begin{tabular}{lcccc}
\hline \hline & Baseline & $\begin{array}{c}\text { Underage Sibling } \\
=\text { Under 4 }\end{array}$ & $\begin{array}{c}\text { Underage Sibling } \\
\text { = Aged 15-19 }\end{array}$ & $\begin{array}{c}\text { Underage Sibling } \\
\text { = Aged 20-25 } \\
(4)\end{array}$ \\
\hline Treatment*Post1986 & $0.008 * * *$ & -0.003 & 0.005 & 0.002 \\
& $(0.003)$ & $(0.004)$ & $(0.004)$ & $(0.004)$ \\
\hline Observations & 182,005 & 96,325 & 96,325 & 96,325 \\
R-squared & 0.098 & 0.101 & 0.100 & 0.100 \\
\hline \hline
\end{tabular}

$* * * \mathrm{p}<0.01, * * \mathrm{p}<0.05, * \mathrm{p}<0.1$ See notes under Table 5. Columns (2)-(4) include the sample of control households only (no sibling between 10-14).

TABLE A.2. Allowing for differential effects of state-level economic growth for children under- and over-14

\begin{tabular}{lccc}
\hline \hline & \multicolumn{2}{c}{ Overall Effects } & Sibling-based Effects \\
\hline & Wages & Employed & Employed \\
\hline & Ages 6-20 & Ages 10-17 & Ages 10-13 \\
& $(1)$ & $(2)$ & $(3)$ \\
\hline Under14*Post1986 & $-0.059^{*}$ & $0.024^{* * *}$ & $0.009^{* *}$ \\
& $(0.034)$ & $(0.005)$ & $(0.004)$ \\
\hline Observations & 33,278 & 330,059 & 180,840 \\
R-squared & 0.296 & 0.172 & 0.098 \\
\hline \hline
\end{tabular}

$* * * \mathrm{p}<0.01, * * \mathrm{p}<0.05, * \mathrm{p}<0.1$ See notes under Tables 4 and 5. For columns (1)-(4) "Treatment" = "Under 14." Additionally each regression includes a state- and year-specific GDP index and its interaction with "Under 14" to allow for state-specific differences in the effect of economic growth for children above and below the ages of 14. State-level GDP index calculated using state-level Census data as reported by IndiaStat (http://www.indiastat.com/). The base year for the index is 1983. 
TABLE A.3. Adding age by time interactions

\begin{tabular}{|c|c|c|c|}
\hline & \multicolumn{3}{|c|}{ Dependent Variable: Employed } \\
\hline & Overa & 11 Effects & Sibling-based Effects \\
\hline & $\begin{array}{l}\text { Age*Post, } \\
\text { Age }^{2 *} \text { Post }\end{array}$ & $\begin{array}{l}\text { Age* Year FE }^{*} \\
\text { Age }^{2 *} \text { Year FE }\end{array}$ & Age FE* Year FE \\
\hline & $\begin{array}{c}\text { Ages } 10-17 \\
\text { (1) }\end{array}$ & $\begin{array}{c}\text { Ages } 10-17 \\
\text { (2) }\end{array}$ & $\begin{array}{c}\text { Ages } 10-13 \\
\text { (3) }\end{array}$ \\
\hline Treatment*Post1986 & $\begin{array}{l}0.015 * * \\
(0.006)\end{array}$ & $\begin{array}{c}0.015 * * * \\
(0.003)\end{array}$ & $\begin{array}{c}0.008 * * * \\
(0.003)\end{array}$ \\
\hline Observations & 332,282 & 332,282 & 182,005 \\
\hline R-squared & 0.173 & 0.173 & 0.099 \\
\hline
\end{tabular}

$* * * \mathrm{p}<0.01, * * \mathrm{p}<0.05, * \mathrm{p}<0.1$ See notes under Tables 4 and 5. For columns (1)-(4) "Treatment=Under 14." Additionally each regression includes the covariates listed above each column.

TABLE A.4. Adding state-by-year fixed effects

\begin{tabular}{lcc}
\hline \hline & Overall Effects & Sibling-based Effects \\
\hline & Ages 10-17 & Ages 10-13 \\
& $(1)$ & $(2)$ \\
\hline Treatment*Post1986 & $0.018^{* * *}$ & $0.007^{* *}$ \\
& $(0.005)$ & $(0.003)$ \\
\hline State-Year FE & Yes & Yes \\
Observations & 332,282 & 182,005 \\
R-squared & 0.167 & 0.092 \\
\hline \hline
\end{tabular}

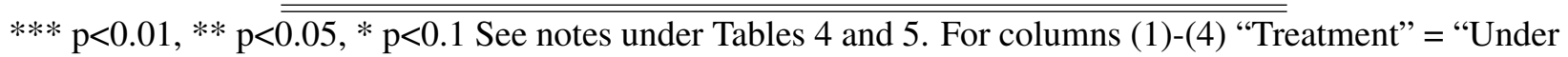
14." Additionally each regression includes state-by-year fixed effects. 